\title{
Iskustva župnika u (ne)ostvarenju Izjava i odluka Druge biskupijske sinode đakovačke i srijemske
}

\author{
IVANA BENDRA* \\ - https://doi.org/10.31823/d.27.1.1 • \\ UDK: 2-46-722.5-733(497.5 Đakovo) • Izvorni znanstveni rad \\ Primljeno: 1. kolovoza 2018. • Prihvaćeno: 12. ožujka 2019.
}

${ }^{*}$ Dr. sc. Ivana Bendra, Institut društvenih znanosti Ivo Pilar Područni centar Vukovar, J.J. Strossmayera 25, 32000 Vukovar, Ivana.Bendra@pilar.hr

Sažetak: U svjetlu promjena koje je u crkvenom djelovanju navijestio Drugi vatikanski koncil te procesa nove evangelizacije kao uobličenja postkoncilskoga nastojanja da odgovori na suvremene izazove i krizu vjere Đakovačka i Srijemska biskupija izdala je 2008. godine Izjave i odluke Druge biskupijske sinode đakovačke i srijemske naslovljene Ti si Krist - za nas i za sve ljude. Njihova je zadaća da budu sredstvo i putokaz u ostvarenju ideje živih kršćanskih zajednica u kojima bi vjernici laici, zajedno s župnicima, aktivno i suodgovorno doprinosili razvitku i pastoralnom djelovanju svojih župa. Stoga je cilj ovoga rada, prigodom desete obljetnice njihova objavljivanja, prikazati rezultate istraživanja koji progovaraju o iskustvima župnika u provođenju sinodskih izjava i odluka. Navedeno će se prikazati temeljem analize ukupno 19 dubinskih intervjua koji su provedeni s župnicima Đakovačko-osječke nadbiskupije u razdoblju od ožujka do svibnja 2018. godine. Analiza prikupljene grade, provedene kvalitativnom metodologijom utemeljene teorije, rezultirala je razvijanjem ukupno 8 kategorija koje s jedne strane prikazuju dosadašnja iskustva župnika u provođenju sinodskih izjava i odluka te sdruge strane nekoliko uzročnika koji, prema njihovu mišljenju, trenutačno dovode do poteškoća u provođenju istih. Uz navedeno analiza upućuje i na nekoliko preporuka koje bi, prema mišljenju župnika, mogle dovesti do poboljšanja u njihovoj daljnjoj provedbi.

Ključne riječi: Izjave i odluke Druge biskupijske sinode đakovačke i srijemske, nova evangelizacija, župnici, tradicionalni vjernici, vjernici laici, kvalitativno istraživanje. 


\section{Uvod i metodološke napomene}

Recentna socioreligijska istraživanja fenomena religioznosti pokazuju da suvremeno hrvatsko društvo i dalje »karakterizira visoka religioznost koja se očituje $u$ tradicionalnom obliku vezanom uz religijske institucije (Crkvu) $\ll .{ }^{1}$ Međutim ona isto tako upozoravaju i na određene promjene koje će se, s obzirom na to da je riječ o jedinom recentnom istraživanju čije se područje provedbe poklapa s većim dijelom područja Đakovačko-osječke nadbiskupije, ${ }^{2}$ ukratko prikazati temeljem rezultata istraživanja koje je 2008. godine proveo Pavić. ${ }^{3}$ Dakle, premda je tim istraživanjem potvrđeno da je na području Slavonije $e^{4}$ dalje najzastupljeniji tradicionalni crkveni, tj. institucionalni tip religioznosti, gdje se $89 \%$ ispitanika smatra religioznom osobom, ${ }^{5}$ od kojih $38,7 \%$ pohađa religijske obrede najmanje jednom tjednom ${ }^{6}$ te $58,3 \%$ u potpunosti prihvaća učenja svoje vjere. ${ }^{7}$ Njime je isto tako utvrđeno kako se $47 \%$ građana slaže ili se potpuno slaže s tvrdnjom da je »moguće biti religiozan na svoj način, dakle bez Crkve $\ll .{ }^{8} \mathrm{Uz}$ navedeno tim je istraživanjem također utvrđeno kako je pohađanje vjerskih obreda najniže u prvim dvjema dobnim kategorijama (do 30 i od 30 do 44 godine), ${ }^{9}$ odnosno da $\gg$ postoji opća tendencija veće prisutnosti postmoderne religioznosti kod mlađe populacije $\ll .{ }^{10} \mathrm{Za}$ takav oblik religioznosti karakterističan je njezin odmak od »tradicionalnog institucionalnog načina validacije religijskih uvjerenja $\ll^{11}$, odnosno $\gg$ sudjelovanje u društvenim grupama i mrežama, ne zbog stvaranja hijerarhije i institucionalne verifikacije religijskih istina, već isključivo kao pomoć $\mathrm{u}$ individualnom duhovnom razvoju $\ll{ }^{12}$

${ }^{1}$ K. NIKODEM, Religija i crkva - pitanja institucionalne religioznosti u suvremenom hrvatskom društvu, u: Socijalna ekologija 20(2011.) 1, 5-30., ovdje 5. U istom radu daje se pregled i drugih autora koji progovaraju o institucionalnom obliku religioznosti kao dominantnom obliku religioznosti u hrvatskom društvu koje, nažalost, zbog prostornih ograničenja rada nije moguće sve navesti.

${ }^{2} \mathrm{~S}$ obzirom na to da se u ovom radu predstavljaju rezultati istraživanja koje je provedeno na području današnje Đakovačko-osječke nadbiskupije, u nastavku će se rada rabiti taj termin, a ne Đakovačka i srijemska biskupija.

${ }^{3}$ Ž. PAVIĆ, Postmoderno društvo i nevidljiva religioznost, Osijek, 2016.

${ }^{4}$ Istraživanje je provedeno na urbanom području grada Osijeka i seoskim sredinama iz triju županija: Požeško-slavonske, Osječko-baranjske i Vukovarsko-srijemske.

${ }^{5}$ Ž. PAVIĆ, Postmoderno društvo i nevidljiva religioznost, 187.

${ }^{6}$ Isto, 177-178.

${ }^{7}$ Isto, 187.

${ }^{8}$ Isto, 184.

${ }^{9}$ Isto, 196.

${ }^{10}$ Isto, 234.

${ }^{11}$ Isto, 243.

${ }^{12}$ Isto, 245. 
Time takav oblik religioznosti, kao i postojeći oblik većinske tradicionalne religioznosti od kojih mnogi, kako to navodi Ivančić, »samo uvećavaju rođenjem broj vjernika $\ll{ }^{13}$, a zapravo ne pokazuju znakove $\gg$ osobne i zrele, obrazložene i svjedočke vjere $\ll,{ }_{1}^{14}$ postaju dvostruki izazov za Katoličku Crkvu, na koji ona pokušava dati odgovor promicanjem nove evangelizacije. Nova evangelizacija kao $\gg$ postupno pokoncilsko uobličenje koncilskih nastojanja Crkve da evanđeoskim duhom iznutra prožme svakoga pojedinca i cijelu društvenu stvarnost ${ }^{15}$ time postaje odgovor Katoličke Crkve na sveopću krizu vjere koja se očituje u opadanju pohađanja religijskih obreda, individualizmu, porastu onih koji ne vjeruju u sve ono što ih poučava njihova religijska zajednica, kao i onih koji su samo nominalni, odnosno rubni vjernici. U takvim nastojanjima Katoličke Crkve do izražaja dolazi ideja vjernika laika i Crkve kao žive zajednice ${ }^{16} \mathrm{u}$ kojoj su svi vjernici pozvani da aktivno i suodgovorno djeluju na svjedočenju i naviještanju evanđelja i širenju svoje vjerske zajednice temeljem »potpunog prihvaćanja i dosljednog življenja u skladu s vlastitom vjerom $\ll{ }^{17}$

U kontekstu takve religijske situacije u suvremenom hrvatskom društvu i aktivnosti koje Katolička Crkva poduzima u približavanju vjerniku, odnosno u svjetlu nove evangelizacije treba promatrati i Izjave i odluke Druge biskupijske sinode dakovačke i srijemske, naslovljene Ti si Krist - za nas i za sve ljude, koje je ista izdala 2008. godine. ${ }^{18}$ Iščitavajući sinodske izjave i odluke, jasno se uočava kako upravo njima ona, kao partikularna Crkva, želi, kroz integralno evangelizacijsko-katehetsko-pastoralno djelovanje, kročiti u takav evangelizacijski proces koji će postupno dovesti do oživljavanja župnih zajednica u kojima bi vjernici, ali i župnici, svjesniji svojega kršćanskoga identiteta, spremno prihvatili istinsko zajedništvo i vlastitu suodgo-

${ }^{13}$ T. IVANČIĆ, Iskustvo nove evangelizacije u Hrvatskoj, u: Bogoslovska smotra 81(2011.)3, 575587., ovdje 581.

${ }^{14}$ IVAN PAVAO II., Ecclesia in Europa, apostolska pobudnica, Zagreb, 2003., br. 50.

${ }^{15}$ N. A. ANČIĆ, Nova evangelizacija - neodgodiva zadaća Crkve našega vremena, u: Crkva u svijetu 35(2000.)2, 189-204., ovdje 193.

${ }^{16} \mathrm{~S}$ obzirom na to da zbog prostornih ograničenja rada u moguće dati detaljniji prikaz sve teološke literature koja o navedenom progovara, počevši od dokumenata Drugoga vatikanskoga koncila, upućuje se na radove u kojima se ona detaljnije navodi i obrazlaže: T. IVANČIĆ, Iskustvo nove evangelizacije u Hrvatskoj, 575-587.; N. A. ANČIĆ, Nova evangelizacija - neodgodiva zadaća Crkve našega vremena, 189-204.; K. STIPANOVIĆ, Drugi vatikanski sabor i vjernici laici, u: Počeci 7(2006.) 1, 9-20. i dr.

${ }^{17}$ I. DEVČIĆ, Vjera i nevjera danas, u: Riječki teološki časopis 21(2013.)1, 37-56., ovdje 54.

${ }^{18}$ Usp. Ti si Krist - za nas i za sve ljude. Izjave i odluke Druge biskupijske sinode dakovačke i srijemske, Đakovo, 2008. 
vornost. ${ }^{19} \mathrm{Na}$ taj način, osobnom preobrazbom, bili bi spremniji i za suočavanje s kušnjama suvremenoga čovjeka, a koje su dijelom posljedica upravo zanemarivanja vlastite duhovne dimenzije, te sposobni za sudjelovanje u daljnjoj evangelizaciji drugih, »istovremeno otvoreni i sposobni za dijalog u pluralizmu postmodernog vremena. $\ll{ }^{20}$ Međutim pojedina istraživanja o dosadašnjem uspjehu u ostvarenju sinodskih izjava i odluka upozoravaju na postojanje određenih poteškoća. U tom smislu izdvojit će se dva istraživanja koja progovaraju o problemu nedovoljnoga ostvarenja uključenosti vjernika laika u župne strukture, ponajprije u župna pastoralna vijeća te pripadajuće im odbore za liturgiju, navještaj, služenje i izgradnju zajedništva. ${ }^{21}$ Naime rezultati analize članova župnih pastoralnih vijeća na području Đakovačko-osječke nadbiskupije, koju Šota temelji na $\gg$ službenim zapisima s dekanatskih susreta članova župnih pastoralnih vijeća i pojedinih odbora održanih u posljednjih pet godina «,22 upozoravaju na postojanje ozbiljnijih poteškoća u strukturiranosti župnih pastoralnih vijeća kao i aktivnom angažmanu vjernika laika. Među ostalim poteškoćama Šota tako upozorava na to da samo 9,8 \% župa ima ustanovljena sva tri odbora, dok čak $42,4 \%$ župa nema ni jedan odbor. ${ }^{23} \mathrm{Uz}$ navedeno drugim istraživanjem o uspješnosti u uključivanju školovanih župnih suradnika u pastoralno-katehetsko djelovanje u župama Đakovačko-osječke nadbiskupije Šota upozorava da i u tom aspektu provedbe izjava i odluka Druge biskupijske sinode postoje određene poteškoće, posebice u pogledu potrebe poboljšanja njihove suradnje $s$ vjeroučiteljima i svećenicima. ${ }^{24}$

Slijedom navedenoga cilj je ovoga rada prikazati rezultate istraživanja kojima se predstavljaju iskustva župnika s područja Đakovačko-osječke nadbiskupije u provođenju danih sinodskih izjava i odluka. Na taj način želi se ponuditi određene odgovore na pitanje zašto su se pojavile poteškoće u njihovu provođenju, ali i uputiti na određene aspekte koji bi mogli dovesti do poboljšanja u njihovoj daljnjoj provedbi.

Kako bi se omogućilo župnicima da progovore o svemu onome što oni smatraju da je bitno iznijeti o temi u pitanju, bez da im se unaprijed postavljaju zadana pitanja, kao istraživačka metoda odabrana je kvalitativna metoda dubinskih intervjua. Tijekom provođenja istraživanja, u razdoblju od ožujka do svibnja 2018. godine, me-

\footnotetext{
${ }^{19}$ Usp. isto, br. 1-13.

${ }^{20}$ Isto, br. 7.

${ }^{21}$ Usp. S. ŠOTA, Analiza i kritički osvrt na župna pastoralna vijeća i njihove odbore u Đakovačkoosječkoj nadbiskupiji, u: Obnovljeni život 71(2016.)1, 85-101.

${ }^{22}$ Isto, 92.

${ }^{23}$ Usp. isto, 94.

${ }^{24}$ Usp. S. ŠOTA, Formacija župnih kateheta u Školi za župne suradnike u Đakovačko-osječkoj nadbiskupiji - analiza i kritički osvrt, u: Diacovensia 21(2013.)3, 431-455.
} 
todološki je odabrano za sudjelovanje ukupno 24 župnika s područja Đakovačkoosječke nadbiskupije, ${ }^{25}$ od kojih je u potpunosti pristalo 17 župnika, djelomično 2, a 5 ih je odbilo sudjelovati. Naime, 2 župnika nisu prihvaćala susret već su se u nekoliko rečenica tijekom telefonskoga razgovora izjasnili o svojim iskustvima u radu koja su također uvrštena u analizu rezultata istraživanja. Nadalje, među 6 odabranih gradskih župa odaziv je stopostotni, dok je svih 5 župnika koji su odbili sudjelovati $\mathrm{u}$ istraživanju s područja seoskih župa. ${ }^{26}$ Intervjui, čijom je transkripcijom dobivena dokumentacija od ukupno oko 150 kartica teksta, u prosjeku su trajali između 45 i 90 minuta. Analiza istih provedena je kvalitativnom metodologijom utemeljene teorije, ${ }^{27} \mathrm{u}$ okviru koje je u obradi podataka primijenjena metoda konstantne komparativne analize. Na taj način iz intervjua su iščitavani sljedeći podatci:

- Podatci koji se odnose na kontekstualne uvjete, a koji prikazuju jednu realnost koja je i odredila potrebu za pronalaženjem odgovarajućega načina u provođenju nove evangelizacije, odnosno sinodskih izjava i odluka, a tiču se današnjega vjernika u suvremenom hrvatskom društvu. Kakav je, prema iskustvima župnika, taj konkretni vjernik? Uz crkvenost promatrao se doživljaj vjere, odnosno prihvaćanje ideje laika i stvaranja žive kršćanske zajednice. Uz navedeno promatralo se i iskustva župnika o svemu onome što određuje današnjega vjernika, odnosno njihovo psihosocijalno stanje, ali i utjecaj društveno-ekonomskih uvjeta i općega ozračja na području Đakovačko-osječke nadbiskupije. Na taj način dobiveni su podatci o mogućnostima župnika za provođenje sinodskih izjava i odluka, odnosno na uspjeh ili neuspjeh župnika u njihovu ostvarenju.

- Uz navedeno analizom su iščitavani podatci koji prikazuju konkretne aktivnosti župnika u odnosu na zadane sinodske izjave i odluke kao i utjecaj uočenih kontekstualnih uvjeta na uspjeh u njihovu ostvarenju. Analiziralo se u kolikoj mjeri župnici uspijevaju pronaći vjernike laike kao aktivne župne suradnike, a samim time onda i u kolikoj mjeri uspijevaju u osnivanju vijeća, odbora, provođenju župne kateheze i ostaloga.

${ }^{25} \mathrm{~S}$ obzirom na to da se želi sačuvati anonimnost ispitanika za način uzorkovanja ispitivača navest će se samo podatak da je riječ o kompaktnoj cjelini koja je odabrana prema dobnom kriteriju.

${ }^{26}$ Izjave pri odbijanju sudjelovanja $u$ istraživanju, poput: $\gg J a ~ u$ tome ne želim sudjelovati. Ma sve

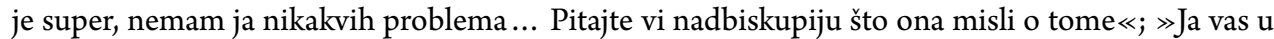
potpunosti podržavam u tome što radite, ali od toga nema nikakve koristi, ništa se neće promijeniti

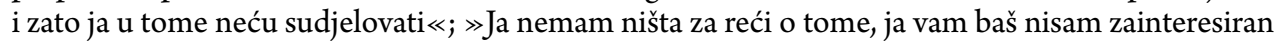
za to «; »Nemam ja vremena za to «, također su znakovite i iz njih se može naslutiti da s jednim dijelom župnika postoje ozbiljne poteškoće u suradnji, odnosno provedbi sinodskih izjava i odluka, čije uzroke zbog nesudjelovanja u istraživanju, nažalost, nije bilo moguće utvrditi.

${ }^{27}$ Usp. A. L. STRAUSS, J. M. CORBIN, Basics of Qualitiative Research: Techniques and Procedures for Developing Grounded Theory, Thousand Oaks - London - New Delhi, 1998. 
- Na koncu analizom je promatran utjecaj takvih međurelacijskih odnosa, s jedne strane na mogućnosti provođenja sinodskih izjava i odluka i s druge strane posljedično na trenutačan stav župnika prema Drugoj biskupijskoj sinodi đakovačkoj i srijemskoj.

Premda primjenom ove metodologije nije razvijena supstantivna utemeljena teorija, već se analiza prikupljenih podataka zadržala na razini razvijanja hipoteza (međurelacijskih odnosa), ${ }^{28}$ ovakav oblik analize prikupljene građe u konačnici je rezultirao razvijanjem ukupno 8 kategorija koje s jedne strane detaljno opisuju dosadašnja iskustva župnika u provođenju sinodskih izjava i odluka te s druge strane upozoravaju na uzroke postojanja poteškoća u provođenju istih:

- tradicionalni vjernik

- stvaranje preduvjeta (problem baze - vjernika, profesionalnih suradnika i volonterstva)

- odnos nadbiskupije i župnika

- integralan pristup i generaliziranje

- pristup župnika

- suradnja s vjeroučiteljima

- župna kateheza

- susreti i seminari na nadbiskupijskoj razini.

Stoga je i konceptualni okvir rada određen u skladu s definiranim kategorijama kojim će se, uz prikaze dosadašnjih iskustava župnika u provođenju sinodskih izjava i odluka te uzroka postojećih poteškoća u njihovu provođenju, zaključiti s nekoliko kratkih promišljanja i preporuka za moguće poboljšanje trenutačnoga stanja i postizanje većega uspjeha u daljnjem radu, a koja se temelje na preporukama samih župnika.

\section{Rezultati istraživanja - prikaz uzroka poteškoća u provođenju Izjava i odluka Druge biskupijske sinode dakovačke i srijemske}

\subsection{Tradicionalni VJeRniK}

Predstavljanje rezultata istraživanja započet će se prikazom profila današnjega vjernika na istraživanom području na način kako ih vide župnici. Prema tipologiji vjernika kojom se koriste župnici uočavaju se samo dvije skupine: tradicionalni vjernici

${ }^{28}$ Usp. J. W. CRESWELL, Qualitative inquiry and research design: Choosing among five approaches, Thousand Oaks - London - New Delhi, 2000. 
i oni rubni. S obzirom na to da su samo dva župnika tijekom provođenja intervjua iznijela svoja promišljanja i iskustva o radu s rubnim vjernicima, što je također znakovito ako se promatra sinodske izjave i odluke kao sredstvo nove evangelizacije s bitnim naglaskom na one vjernike koji su se udaljili od vlastite vjere, u radu će se usredotočiti samo na prikaz tradicionalnih vjernika. Na koji način župnici opisuju tradicionalnoga vjernika? U odnosu na crkvenost župnici navode da je riječ o prosječno 20-25\% onih koji su redoviti na nedjeljnim misama. No isto tako navode kako je prema dobnoj strukturi u toj skupini uglavnom riječ o starijim osobama i djeci, tek povremeno majkama, dok su cijele obitelji na misama vrlo rijetke. Ti podatci, u odnosu na socioreligijsko istraživanje koje je proveo Pavić, poklapaju se u pogledu strukture onih koji su redoviti u pohađanju religijskih obreda. Međutim, dok Pavić navodi da se njihov broj kreće oko $38 \%$, ovo istraživanje, s odmakom od deset godina, upozorava na znatno smanjenje onih vjernika koji su redoviti u pohađanju religijskih obreda.

No ono što nije uobičajeno, barem prema autoru dostupnoj socioreligijskoj literaturi, ${ }^{29}$ a što je za ovo istraživanje mnogo znakovitije, jest prikazati kakvi su današnji vjernici u odnosu na poimanje sebe kao laika, kao aktivnoga člana Crkve, koji je »pozvan da pridonese posvećenju svijeta vlastitim svjedočenjem vjere $\ll,{ }^{30} \mathrm{u}$ onom smislu kako je to vidljivo iz dokumenata Drugoga vatikanskoga koncila. Je li među vjernicima Đakovačko-osječke nadbiskupije zaživjela ideja laika kao aktivno uključenoga suodgovornoga člana svoje vjerske zajednice? Prema izjavama župnika o mentalitetu današnjega tradicionalnoga vjernika može se zaključiti da ona još uvijek nije zaživjela: »Sinoda je imala stvarno onako za cilj dati odgovore na pitanja koja su se pojavila evo s tim novim vremenima koja su došla. I mi smo, koji smo to htjeli, pronašli u tome dovoljno materijala i prema tome djelujemo. Međutim, najveća stvar koja zapravo nije zaživjela je taj laik, koji je sada dobio prostor unutar Crkve. Znači taj Drugi vatikanski koncil desetljećima još nije zaživio u mentalitetu našega čovjeka.« (sugovornik 4) Naime većina župnika svoje vjernike, čak i one zrele ili praktične, ${ }^{31}$ opisuje kao vjernike kojima je vjera bitna u životu, imaju izraženu crkvenost, međutim imaju jedan »pretkoncilski odnos prema Crkvi« (sugovornik 12), odnosno nisu u mnogim značajkama prihvatili svoju veću angažiranost, pa čak ni drugih, te su se naviknuli da sve aktivnosti poduzima isključivo župnik. Stoga ih župnici opisuju kao nezainteresirane, pesimistične, opterećene materijal-

${ }^{29} \mathrm{~S}$ druge strane isto je relativno zastupljena tema u teološkoj literaturi. Usp. N. A. ANČIĆ, Nova evangelizacija - neodgodiva zadaća Crkve našega vremena, 189-204.; J. GRBAC, Vjernik laik u Crkvi, u: Riječki teološki časopis 12(2004.)2, 399-408. i dr.

${ }^{30} \mathrm{~K}$. STIPANOVIĆ, Drugi vatikanski sabor i vjernici laici, 20.

${ }^{31}$ Usp. P. ARAČIĆ, G. ČRPIĆ, Kršćanski identitet: skica za idealtip vjernika kršćanina, u: P. ARAČIĆ, I. DŽINIĆ, B. HLAVAČEK (ur.), Kršćanski identitet i obitelj, Đakovo, 2011., 15-64. 
nim i egzistencijalnim, koje je jako teško animirati za bilo kakav oblik suradnje: »Sinoda polazi iz nekakvog uporišta da današnji čovjek želi, da traži, da hoće, da su ljudi zainteresirani, a mi svećenici nekako kao ne bi, pa ne bi. A u biti sve više i sve češće je situacija obratna. Današnji čovjek obično nema interesa, osim za ono što njega stvarno zanima ... Kad su u pitanju odrasli vjernici, ja bih rekao da je primjetna jedna nezainteresiranost. Ne znam da li je to rezultat i neke sveopće melankolije i nekog ne baš prevelikog optimizma, odnosno čak pesimizma koji je prisutan u Slavoniji, onako kao da su ljudi pomalo nezainteresirani za bilo što.« (sugovornik 2)

Kao jedan od razloga takvoga odnosa prema vlastitom angažmanu u župnoj zajednici, za koji župnici navode da je podjednako prisutan i u gradskim i u seoskim župama, župnici ističu izraženu prisutnost ostataka komunističkoga mentaliteta kod velikoga broja vjernika, posebice starijega dijela stanovništva, za vrijeme kojega nisu »navikli biti suodgovorni u društvenoj, pa tako ni u crkvenoj zajednici« (sugovornik 1). Takve okolnosti dovele su do toga da kod mnogih vjernika nemamo razvijen kršćanski identitet u onom smislu da su među njima trebale zaživjeti ideje Drugoga vatikanskoga koncila, pa onda i same Izjave i odluke Druge biskupijske sinode đakovačke i srijemske, zbog čega župnici velik dio poteškoća u radu sa suradnicima vjernicima laicima povezuje upravo $s$ takvim mentalitetom. Dugogodišnji život u takvom sustavu ostavio je,među ostalim, kao posljedicu i doživljaj vjere kao nečega intimnoga i privatnoga na što se onda samo nadovezuju dodatni izazovi današnjega suvremenoga, postmodernoga društva, u kojemu je takav vjernik dodatno opterećen duhovnom krizom izazvanom promicanjem neoliberalnih vrijednosti i ponovnim promicanjem vjere kao nečega intimnoga i privatnoga.

Uz navedeno, kao dodatno otežavajuće okolnosti za provođenje sinodskih izjava i odluka župnici spominju trenutačne društveno-ekonomske uvjete na istraživanom području, prije svega problem velike nezaposlenosti, odnosno opterećenosti vjernika vlastitom egzistencijom i neispunjenih očekivanja o kvaliteti života na ovom području nakon Domovinskoga rata: $\gg$ To su ljudi koji su sami po sebi ogorčeni i izgubljeni... Ozračje opće društvene klime u kojem se ljudi nalaze je takvo da su ljudi nezadovoljni, depresivni, melankolični, očekivanja su bila puno veća u ovom kraju nakon Domovinskoga rata općenito o kvaliteti života.« (sugovornik 17)

Isto tako župnici navode i problem depopulacije, odnosno $\gg$ mrtvih župa «, koji se očituje u činjenici da se među ukupno 19 istraživanih župa u čak 15 župa (78 \%) $\mathrm{rađa} / \mathrm{krsti}$ manje djece nego što umire stanovnika/vjernika. Tek u dvjema župama (10\%) taj je broj otprilike podjednak, dok se u samo dvjema župama (10\%) više rađa, odnosno krsti djece nego što umire vjernika.

Na koncu župnici ističu da, uz već uočeni trend pada broja krštene djece u odnosu na broj umrlih vjernika, sada situacija postaje u većini župa vrlo kritična, a uzrokuje 
ju problem masovnoga iseljavanja: $\gg$ Mi se ne možemo distancirati ni od ozračja društva u kojem živimo. Ono što ja vidim jest da kod nas u Slavoniji ima dosta tromosti i pasivnosti i to se nužno infiltrira i u život župnih zajednica. Pa onda i ta neimaština, pa ovaj val iseljavanja ... Dakle, može se nabrojati više faktora koji ne idu u prilog produbljenju vjere, a mi ne možemo onu šačicu vući u sve.« (sugovornik 14) Navedeno župnici potkrepljuju dokazima s evidencija blagoslova kuća koji pokazuju da se iz gotovo svih župa Đakovačko-osječke nadbiskupije ljudi masovno iseljavaju, odnosno da je broj stanovnika u pojedinim župama u odnosu na posljednji popis stanovništva iz 2011. godine sada i nekoliko stotina manji. Jedan župnik to ilustrira primjerom da se u njegovoj župi od ukupno 350 kuća nalazi 100 praznih kuća u kojima nitko ne živi te 46 kuća u kojima živi samo jedna starija osoba (sugovornik 19). Time takvi rezultati o uvjetima za uspješno provođenje sinodskih izjava i odluka, a koji se u najvećoj mjeri ipak tiču mentaliteta današnjega vjernika, upućuju na moguće poteškoće u radu župnika i njihovu provođenju. Na takav zaključak dodatno upućuje i činjenica da je među praktičnim vjernicima, dakle među onima koji imaju izraženu crkvenost i od kojih župnici očekuju najveću zauzetost, riječ o staračkoj populaciji, zbog svoje dobi nespremnoj za veći angažman. No podatci isto tako pokazuju da se takav negativan trend može nastaviti i u budućnosti, na što posebice upućuje činjenica da su, prema izjavama župnika, djeca druga najveća skupina koja ima izraženiju crkvenost. Naime župnici navode da je za njihovu izraženiju crkvenost dijelom zaslužna činjenica da se oni nalaze u životnom periodu kada su zbog pripreme za primanje sakramenata prve pričesti i potvrde relativno redovito nazočni na nedjeljnim svetim misama, dok će na njihovu daljnju crkvenost i uključenost $u$ život župne zajednice u značajnoj mjeri utjecati razina crkvenosti i uključenosti u život župne zajednice njihovih roditelja. $U$ tom smislu župnici vide provođenje sinodskih izjava i odluka kao dugoročan problem jer današnje suvremene obitelji u velikoj mjeri pokazuju stavove koji ne idu njima u prilog. Tako župnici navode da današnje obitelji nemaju razvijenu kulturu nedjelje što ilustriraju mnogobrojnim primjerima, poput roditelja koji samo dovedu dijete na $\gg$ nedjeljnu misu i onda odu preko puta crkve u kafić ili ih dovedu samo na kraj mise kako bi dobili potvrdu da su bili prisutni na misi, ukoliko je riječ o prvopričesnicima (sugovornik 9). Uz navedeno župnici spominju i druge poteškoće s kojima se sve češće susreću u radu s obiteljima, a koje dodatno potvrđuju problem nezaživljenosti ideje žive župne zajednice među današnjim vjernicima. Tako navode da se sve učestalije susreću sa stavom roditelja da župna kateheza od 1. do 8. razreda nije potrebna jer imaju školski vjeronauk. Isto tako župnici navode da su to obitelji koje su uglavnom nezainteresirane za bilo kakve susrete i kateheze, zbog čega samo 2 župnika uspijevaju u okupljanju roditelja na susretima u pripravi njihove djece za primanje sakramenta prve pričesti ili potvrde. Navedeno dodatno pojačava činjenica da roditelji sve učestalije traže primanje sakramenta krštenja za njihovu djecu mimo nedjeljne 
mise, čime pokazuju kako ne prihvaćaju sakrament krštenja kao ulazak u župnu zajednicu. Isto tako župnici navode da je sve veći broj obitelji koje svoju djecu šalju na primanje sakramenata iz običaja, posebice potvrde jer ide cijeli razred, što se onda odražava na njihov odnos prema župnoj katehezi te na neredovito pohađanje. U konačnici, svi župnici ističu da imaju velikih poteškoća u pronalaženju obitelji koje bi bile spremne aktivno se i suodgovorno uključiti u život župne zajednice i na taj način svjedočiti vlastitu vjeru drugima. Time takvi rezultati pokazuju kako se ni nakon deset godina od objavljivanja Izjava i odluka Druge biskupijske sinode dakovačke i srijemske nisu postigli značajniji uspjesi u provedbi nove evangelizacije. Isti se očituju u činjenici da je, prema mišljenju župnika, velika većina vjernika još uvijek otuđena od vlastite vjere, odnosno još uvijek ne prihvaća ideju vjernika laika kao aktivnoga i suodgovornoga člana vlastite župne zajednice. Time oni isto tako upućuju na to da je moguće očekivati u velikom broju župa i poteškoće u provođenju sinodskih izjava i odluka, ako ih se promatra u odnosu na postojanje aktivnih suradnika, članova odbora, odnosno upućuju na to da je u trenutačnim uvjetima moguće očekivati poteškoće u provođenju kvalitetnoga evangelizacijsko-katehetsko-pastoralnoga rada i djelovanja. Da poteškoće uistinu i postoje pokazuju sljedeći podatci iz kojih je vidljivo u kolikoj mjeri župnici uspijevaju pronaći vjernike laike kao župne suradnike te uspijevaju li imati aktivna vijeća i pojedine odbore. Naime ukupno 8 župnika (42\%) nema ni jednoga suradnika vjernika laika ni vjeroučitelja koji su s njime uključeni u župne aktivnosti. Samo 3 župnika (15\%) navode da imaju i suradnike i vjeroučitelje, dok 2 župnika ( $10 \%)$ imaju pomoć samo od vjeroučitelja. Na koncu 6 župnika (32\%) ističe kako imaju pomoć samo župnih suradnika, od kojih dvojica navode da je riječ samo o jednoj osobi. Takvi rezultati odražavaju se posljedično i na uspješnost u radu pastoralnoga i ekonomskoga vijeća te odbora za liturgiju, navještaj, služenje i izgradnju zajedništva koje bi, prema sinodskim izjavama i odlukama, trebala imati svaka župa. ${ }^{32}$ Naime, premda svi župnici navode da imaju oformljena pastoralna i ekonomska vijeća, oni isto tako naglašavaju kako ona, kao ni odbori, uglavnom ne funkcioniraju u onom smislu kako se to od njih traži prema Izjavama i odlukama Druge biskupijske sinode dakovačke i srijemske, a prema kojima bi u svakom župnom pastoralnom vijeću trebali biti zasebni vijećnici u broju od 6 do 20 članova: ${ }^{33} \gg$ Mi jesmo to onako podijeljeno formirali, ali nemamo zasebne susrete, imamo zajedničke, ali se zna otprilike tko je više u kojem dijelu angažiran.« (sugovornik 2). Rezultati istraživanja pokazuju da župnici zapravo imaju vrlo mali broj suradnika i vjernika laika koji su onda praktički uključeni u sve aktivnosti u jednoj župi: »Mi u našoj Crkvi stvarno imamo široku lepezu mogućnosti da se čovjek osjeća dijelom zajednice, ali mi tu knjigu jednostavno ne

\footnotetext{
${ }^{32}$ Usp. Ti si Krist - za nas i za sve ljude, br. 130-132, 205-207, 346, 575.

${ }^{33}$ Usp. isto, br. 577.
} 
možemo provesti u djelo. Bojimo se da je ljudi jednostavno ne mogu apsolvirati, ne mogu sve ono što mi hoćemo, ljudi to jednostavno ne mogu... To je činjenica, jer nama su jedno te isti ljudi u pastoralnom i ekonomskom vijeću, pjevači, čitači, suradnici u ovome, suradnici u onome.« (sugovornik 4)

Uz navedeno ukupno 5 župnika ( $26 \%)$ ističe da ni nema odbore, osim liturgijskoga, koji u onom tradicionalnom smislu uglavnom funkcionira u svim župama, dok 6 župnika (32\%) navodi da najuspješnije funkcionira suradnja s laicima u okviru karitativnoga odbora.

Dakle, premda je istraživanje pokazalo kako samo jedan župnik smatra da $\gg$ neke stvari nije dobro miješati s vjernicima laicima « (sugovornik 4) te da samo 2 župni-

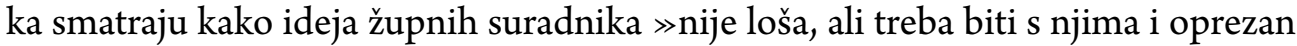
te da su oni više potrebni u gradskim župama « (sugovornik 6), odnosno da većina župnika ističe suradnju vjernika laika kao nešto pozitivno, kao temeljni problem pojavljuje se činjenica nedovoljnoga broja istih, odnosno velik postotak vjernika koji nisu spremni uistinu svjedočiti svoju vjeru i suodgovorno sa župnikom djelovati na području svoje župe u evangelizacijsko-pastoralno-katehetskom radu. Time se potvrđuje da do velikoga broja vjernika Đakovačko-osječke nadbiskupije sinodalnost još nije doprla te da još uvijek doživljavaju Crkvu kao jednu zatvorenu strukturu u kojoj nema odgovornosti vjernika: »Dakle, ovdje na župi postoje sva tri odbora. Pastoralno vijeće radi, ekonomsko vijeće radi. Ja sam ih natjerao, razumijete! Ali to je razlika kada vi nemate odgovor odozdo, nego natjerao ih, jer nema druge mogućnosti. Dakle, radi se o jednoj jednostavnoj stvari. Još uvijek nije svijest vjernika takva da bi se oni, kako bih rekao, Crkva se još uvijek općenito doživljava kroz strukturu, nema odgovornosti vjernika. Zato što sve stvari dolaze odozgo i idu dolje, takva je navika. Sistem shvaćanja crkvenosti je sistem zapovijedanja. Dakle, ustanova koja odozgo dolje zapovijeda, a ne ustanova zajednice.« (sugovornik 1) Prema župnicima taj se problem posebice očituje u manjim seoskim sredinama $u$ kojima je župnicima još zahtjevnije pronaći aktivne i suodgovorne vjernike laike: $\gg$ Jedno je teorija, a drugo je praksa. Kad ja nešto trebam, pa se svatko ispriča. Što da ja očekujem, to je vrlo zahtjevno od laika, da imamo te odbore, da imamo te sjednice. U svim tim odborima, uvijek se miješaju isti ljudi. Koje ne možeš dobiti, ne možeš. To pastoralno i ekonomsko vijeće, tu vi sazovete njih šestoricu i sve iznesete, a oni kažu to će te vi velečasni. Tako je u svim župama... Imamo mi te odbore, onako kako oni traže to su priče za malu djecu i uvijek se svodi na ono ma velečasni pusti me na miru. Te odbore, to je jako lijepo napisati, ali u praksi to nije baš tako.« (sugovornik 10)

Slijedom takvih iskustava župnika u provođenju sinodskih izjava i odluka rezultati istraživanja pokazuju kako su ona posljedično utjecala i na razvijanje različi- 
tih stavova među njima o samoj Drugoj sinodi. Tako rezultati pokazuju da samo 3 župnika ( $15 \%)$ imaju u potpunosti pozitivan stav prema Drugoj sinodi i nastoje primjenjivati sinodske izjave i odluke u svakodnevnom pastoralno-katehetskoevangelizacijskom radu i djelovanju. No ovdje je bitno naglasiti da i od tih triju župnika samo jedan smatra da ima uspješan pastoralni život u svojoj župnoj zajednici. Ukupno 6 župnika (31\%) smatra sinodske izjave i odluke ideal-tipski dobro postavljenim, međutim drže da ne odgovaraju trenutačnom stanju, mogućnostima i potrebama Đakovačko-osječke nadbiskupije. Ovdje, kao što će se vidjeti u nastavku rada, župnici prije svega navode problem nepostojanja preduvjeta, volonterstva, problem generaliziranja i integralnoga pristupa, neujednačenoga pristupa župnika, odnosa župnika i nadbiskupije, kao i neuzimanja u obzir realnih mogućnosti za njihovo provođenje prema strukturama pojedinih župa.

Isto tako rezultatima ovoga istraživanja utvrđeno je kako ukupno 10 župnika (52\%) ima negativan stav prema Drugoj sinodi, među kojima su 3 župnika (15\%) koji ju uopće ne prihvaćaju i smatraju da ona nije donijela nikakve promjene u njihovu radu. Preostalih 7 župnika (37 \%) u vrlo malom postotku primjenjuju njezine zaključke, a kao razloge također navode problem u njihovu nametanju, integralnom pristupu i generaliziranju, odnosno neuzimanju u obzir strukture pojedinih župa u stvaranju preduvjeta i odnosu nadbiskupije i župnika.

U prilog takvim dosta poražavajućim statističkim podatcima o trenutačnim uspjesima župnika u provođenju sinodskih izjava i odluka, a posljedično onda i o samim stavovima župnika prema istima, u nastavku rada iznose se detaljnija pojašnjenja i o preostalim kategorijama koje, uz kategoriju koja progovara o nezaživljenosti ideje vjernika laika kao aktivnoga i suodgovornoga člana vlastite župne zajednice među tradicionalnim vjernicima, upućuju na promišljanja župnika o dodatnim uzrocima koji dovode do poteškoća u njihovu provođenju.

\subsection{STVARANJE PREDUVJETA}

Uz kategoriju koja progovara o (ne)zaživljenosti sinodskih izjava i odluka među tradicionalnim vjernicima prema zastupljenosti u iskustvima župnika na drugom se mjestu nalazi kategorija naslovljena Stvaranje preduvjeta. Naime, neovisno o tome doživljavaju li intervjuirani župnici Drugu sinodu na pozitivan ili negativan način, kod ukupno 16 (84 \%) župnika jasno se uočava povezivanje poteškoća u provođenju sinodskih izjava i odluka s činjenicom da još uvijek nisu stvoreni preduvjeti za njihovo uspješnije ostvarenje: »Mi smo napravili dobre smjernice. Ja mislim da, ne bih htio reći da je sve loše kada je u pitanju Druga sinoda. Nekakve smjernice su bile dobre i stvarno jesu dobre. Međutim, mi nemamo preduvjete.« (sugovornik 2) $\mathrm{Na}$ kakve preduvjete konkretno misle? Odgovor na postavljeno pitanje zapravo se nadovezuje na prethodnu kategoriju, gdje ukupno 16 župnika progovara upravo o 
problemu (ne)zaživljenosti ideje laika kao aktivnoga i suodgovornoga člana svoje vjerske zajednice. Naime tom su kategorijom prikazana promišljanja onih župnika koji naglašavaju da bi se za postizanje većega uspjeha u provođenju sinodskih izjava i odluka trebalo vratiti na samu $b a z u$, na vjernike, a koja se prema njihovu mišljenju preskočila: »Ja sam isto prošao u sebi kao svećenik tu jednu oduševljenost i nekakav zanos nekako u želji da Sinoda zaživi, da se ona spusti u stvarnost, a onda sam vidio da sam pucao iznad glava, da tako kažem, ljudi i htio nešto provoditi, a onda sam vidio da to ne može na silu provoditi, neću reći na silu, ako nema pretpostavka u bazi, ako to ne sjeda, ako se negdje ne susretne i ona izgrađenost vjernika i župne zajednice i onda ono što ti spuštaš u nju.« (sugovornik 14) Upravo takav pristup, kojim se nastoji prvo provoditi struktura, a ne rad s vjernicima među kojima je prisutan nedostatak istinskoga iskustva vjere, prema ovim je župnicima doveo do postojećih poteškoća: »Sinoda je jedna profesorska ideja koja ne dotiče život. To znači da se ide prvo praviti struktura, bez nekakvog unutarnjeg pokretača. Sad je pitanje što je taj unutarnji pokretač? Za mene je on osobno iskustvo i to mora biti središte svega, kako sinode tako i nove evangelizacije. Znači ovo sve skupa ne pije vodu i ja mislim da ćemo mi uskoro izgubiti vjernike jer jako promašujemo u svojem radu. Sve temeljimo na povijesnom vremenu tradicionalne religije, a kada umru ti tradicionalni vjernici nećemo imati novih jer nemaju iskustvo vjere. A po meni bi bilo najbitnije da Crkva bude sposobna ljude dovesti do toga iskustva. Onda može ići dalje evangelizacija.« (sugovornik 5) Stoga ova skupina župnika smatra da se sinodske izjave i odluke treba provoditi etapno, ${ }^{34}$ odnosno drže nužnom promjenu postojećih metoda kojima se ne postižu veći uspjesi u novoj evangelizaciji, a onda ni u provedbi sinodskih izjava i odluka.

Nadalje među ovom skupinom župnika koji progovaraju o potrebi stvaranja preduvjeta ukupno 6 župnika ( $32 \%$ ) upozorava i na problem volontiranja. Pritom upućuju na potrebu promišljanja o odgovarajućoj profesionalizaciji suradnika te upozoravaju na to kako su poteškoće u pronalaženju suradnika prouzrokovane možda upravo činjenicom da se njihov angažman temelji na volonterstvu: »To je po mom mišljenju jako dobro jer se, $s$ jedne strane, nas rasterećuje, a s druge strane vi imate tih vjernika laika koji puno bolje znaju raditi posao vezano uz pastoral nego svećenici, ali to za sobom nosi pitanje financiranja i nosi za sobom pitanje da li mi imamo malo suradnika zato što izostaje financijska pomoć. Oni nas neće odbiti ali će se izvlačiti, a time bi se možda moglo pomoći na neki način onima koji su u potrebi.« (sugovornik 7) Stoga naglašavaju potrebu odgovarajuće financijske potpore angažiranim suradnicima, čime Crkva ujedno može doprinijeti i poboljšanju negativnih

${ }^{34}$ Usp. P. KVATERNIK, Nova evangelizacija traži i novi pastoral, u: Bogoslovska smotra 82(2012.)1, 177-192. 
demografsko-ekonomskih trendova na području Đakovačko-osječke nadbiskupije: »Vi možda imate nekog suradnika koji je bio spreman i pokazao interes da se školuje za župnog suradnika, ali on jednostavno ima i druge obaveze. Ja ne mogu očekivati od njega da on to sve savršeno pripremi po svim pravilima, recimo nekakav katehetski susret. E sad, Sinoda, onako kako je ona to predvidjela, usmjerila, ona traži nekako i više. $U$ tom smislu bi svakako valjalo razmišljati i o nekakvim profesionalcima.« (sugovornik 2) U okviru toga ističu i potrebu razmatranja ideje veće angažiranosti i zapošljavanja, barem honorarno, nezaposlenih vjeroučitelja $s$ područja nadbiskupije: »S druge strane, imamo problematiku vjeroučitelja na burzi pa neka to bude plod Sinode gdje bi se vjeroučitelji uklopili u rad župne zajednice, da im župna zajednica pomaže i daje nekakvu plaću.«(sugovornik 8)

\subsection{ODNOS NADBISKUPIJE I ŽUPNIKA}

Sljedeća kategorija progovara o odnosu župnika i nadbiskupije, koji kao uzrok poteškoća u provođenju sinodskih izjava i odluka navodi ukupno 15 župnika (79\%). Među tim župnicima primjetno je doživljavanje Druge sinode kao određenoga oblika nametanja: $\gg$ Sinodske promjene doživljavaju se kao nametnute... Sinodalni duh zajedničkog hoda, zajedničkog razmišljanja, zajedničke odgovornosti, duh slušanja, to je ono najvažnije u sinodi, jednostavno ne ide« (sugovornik 1), kojima nadbiskupija stvara pritisak župnicima za njihovo provođenje bez adekvatne međusobne komunikacije o realnim mogućnostima i adekvatnom načinu provođenja istih: $\gg$ Mi imamo stalno jedan pritisak odozgo. Treba ovo, treba ono, a onda to kod određenog broja svećenika rezultira time da kažu mi nećemo ništa. A onda neki se trude, a onda ispada kao da se ne trude dovoljno, pa su krivi i za ono što su radili. Pa onda čovjek misli pa bolje da nisam ni ja ništa radio.« (sugovornik 2) U kontekstu navedenoga među tim je župnicima primjetno i naglašavanje da postoji određeni broj župnika koji nisu educirani za provođenje sinodskih izjava i odluka, ali i da postoji problem postojanja različitih struktura župa, za što, prema njima, nadbiskupija nema dovoljno razumijevanja: »Što se tiče Sinode, ja ju baš ne volim, zato nisam htio pričati o njoj. Nisam je nikada prihvatio kao nešto svoje zbog toga što je to nametnuto, a kada je sve nametnuto onda dolazi do otpora, a svećenici nisu izučeni, nisu prihvatili i automatski te odluke doživljavaju otpor od naših svećenika. Znači nisi ukinuo staro, a nisi izučio za novo. Nastavlja se po starom, a mora se uključiti i novo. Onda nam se ne da ništa raditi, nego nastaviš kako je išlo i to je to. Evo to odražava svu istinu.« (sugovornik 8$)$

\subsection{INTEGRALAN PRISTUP I GENERALIZIRANJE}

Nadalje, ukupno 12 župnika (63\%) pronalazi uzrok za trenutačno postojanje poteškoća i u primjeni integralnoga i generalizirajućega pristupa. Naime župnici na- 
vode da trenutačne metode koje se primjenjuju u provođenju sinodskih izjava i odluka iziskuju provedbu širokoga spektra aktivnosti na pojedinoj župi, koju samu po sebi župnici vide kao pogrješan pristup. Zbog čega? Prije svega jer takav pristup podrazumijeva i očekuje jednak uspjeh i na gradskim i na seoskim župama, što je po njima nerealno očekivati s obzirom na strukturu stanovništva pojedinih župa, posebice manjih seoskih: »Idemo tražiti u Božjoj riječi, idemo tražiti u nekakvim potrebama, ali ne previše široko, ne previše trgovački. Ne tako da se mi osjećamo u Crkvi kao u Portanovi gdje imamo sve i svašta, a u stvari nemamo ništa. Nego ajmo se uhvatiti jedne stvari, onoga što je kritično i idemo riješiti do kraja. Na možemo se sa sto problema hvatati. I onda u isto vrijeme vi svećenici će te to rješavati ... Mislim da kada bi oni nama rekli, svećenici imate taj i taj problem, ajmo ga probati riješiti, da vidimo što se može napraviti, ali na temelju svojih mogućnosti, a ne sad, meni je najgore kada oni uspoređuju jednu zajednicu u gradu i iste funkcije moraju biti u nekoj zajednici na selu.« (sugovornik 8) Naime župnici navode da je u manjim seoskim župama mogućnost za pronalaženje suradnika vjernika laika vrlo mala, $\mathrm{u}$ okviru čega ističu i mnogo veću zastupljenost neprihvaćanja ideje vjernika laika kao suradnika u takvim sredinama: »Sredina je takva da oni kažu: 'Župniče, mi ćemo doći u Crkvu, mi ćemo se moliti, mi ćemo dati milostinju, ali vi znate najbolje...' Zatim, to je relativno mala sredina, tradicionalna sredina, nije da ljudi ne bi htjeli, ali tu je nekakav ljudski obzir. 'Od kud sad ona to da radi? Ona da moje dijete podučava? Ma znam ja i nju i njezine. Pa neka napravi reda prvo u svojoj kući.'« (sugovornik 7)

Ta skupina župnika također ističe kako se takvim poticanjem mnogobrojnih događanja tijekom tjedna na pojedinim župama gubi nedjeljna euharistija kao središte i najsvečanije slavlje kršćanske zajednice, odnosno da se poticanjem istih zanemaruje temeljni problem crkvenosti na koji bi se, prema njihovu mišljenju, trebao staviti naglasak: »Kod nas se u ovom pastoralu koji je donijela Sinoda, dakle sve se to razvodnilo na ovo i na ono, a nedjelja je ostala negdje po strani, a na kojoj treba biti naglasak... A nedjelja je po meni u tim pastoralnim naglascima sinode trebala biti u centru našega djelovanja. A onda on napunjen tim duhom, pričešću, tom riječju Božjom, ide u taj tjedan i živi od te nedjelje. Sve ostalo je isto bitno, ali u svemu tome jednostavno se izgubiš... Onda na neki način postaješ nezadovoljan svećenik. Oni će danas sve drugo prije nego na misu, a za to smo sami krivi, ne samo društvo. Možemo mi sada lajati po toj liberalnoj ideologiji, ali mi nismo ljudima stavili akcenat na tu nedjelju. Sad očekivati od njih uključenost u pastoral, u katehezu i sve ostalo uz svoj ritam, uz posao, a vidiš kako se danas teško živi. Ljudi odlaze van, oni koji rade, rade za minimalac, teško preživljavaju, bore se za taj život koji imaju. E sada u takvoj jednoj situaciji, u kojoj nam jeste teško, sada ti još njima pristupaš kao da je sve normalno. Oni kao da ne žive u ovom vremenu.« (sugovornik 15) 


\subsection{PRISTUP ŽUPNIKA}

Uz do sada izneseno ukupno 7 župnika (37\%) vidi uzrok postojećih poteškoća i u samim župnicima: »A župnik ili svećenik bi morao zaista biti ono u pravom smislu svećenik, kako nas Crkva uči, znači zato se i ne ženimo da se cijeli damo Crkvi. E sad, gdje su nam takvi? Kada bismo takvih svećenika imali, župe bi nam cvjetale. Znači mi nemamo takvih svećenika. Ja osobno krećem od sebe, nikoga ne prozivam, sebe prvoga. Znam kada bih sebe dao cijelog, kao što me vjera uči što znači biti svećenik, Bogu na raspolaganju sto posto. Onda bi cvjetala više nego što cvjeta sada. Kada ja ne bih imao nekih svojih hobija, nekih svojih želja, ludosti i tako dalje... (sugovornik 18), u okviru čega kao najveći problem ističu neujednačenost u radu i provođenju sinodskih izjava i odluka pojedinih župnika: »Ono najgore na ovoj biskupiji je to što je sve prepušteno stihijski tome kako župnik hoće i zato smo osuđeni na propast. Cijela Crkva će propasti zato što se sve radi stihijski. Sve se radi na način, ovaj svećenik radi to, ovaj ne radi, a ti dođeš iza njega. Nema jedne konstante, kako dođe koji župnik tako se sve mijenja. Sve je prepušteno mojim darovima ili ne-darovima ili karizmama, a ljudi koji su na župi oni najviše pate.« (sugovornik 8) Stoga ističu potrebu čvršćega stava nadbiskupije o tome: $\gg$ Ja sam tu knjigu prostudirao dobrano i bio sam postsinodski svećenik i pokušao gurati mnoge stvari. Neminovno je da je dosta teško negdje to provoditi, ali i samo načelno biskupija je dosta spora u svojoj sinodi, sa njezine strane u provođenju toga. Spori su vrlo i u reagiranju i u ostvarivanju i poticanju onoga što njima Sinoda omogućava da prerežu neku stvar, a ne da čekaju da netko umre ili da nešto izumre, da prerežu stvari i idemo. Do sada smo išli ovako, sada je sinoda obvezujuća. Toga nema, ona je za sada hoćeš, nećeš.« (sugovornik 13) Isto tako naglašavaju i potrebu pružanja pomoći nadbiskupije onim župnicima kojima nedostaje dara za provođenje pojedinih segmenata pastoralno-katehetsko-evangelizacijskoga rada i djelovanja prema sinodskim izjavama i odlukama: »Problem je neminovno dvostrani. $S$ jedne strane imate problem različitog mentaliteta vjernika, a s druge strane $\mathrm{i}$ različite pristupe $\mathrm{u}$ radu svećenika. Ja sam ovakve naravi, milost mi je dao Bog sukladno mojoj naravi. Iza mene će doći netko drugi kojemu će Bog dati milost sukladno njegovoj naravi i koji neće biti usmjeren na katehezu za odrasle i za ovo i za ono jer jednostavno on možda nije obdaren darom za to. Zato i je nužno da biskupija bude puno jasnija i jača, koja bi vodila, jer ako župnik u jednoj župi, koji je prekrasan svećenik i jako dobar upravitelj župe, nema talenta komunikacije onda je tu biskupija ona koja treba reagirati i reći da se kroz školu župnih suradnika oformi njemu pomoć.« (sugovornik 13)

$\mathrm{Na}$ koncu ističu i potrebu suočavanja nadbiskupije s onim župnicima koji se ne uspijevaju distancirati od ozračja koje ih okružuje, koji i sami pokazuju znakove zahvaćanja konformizma, individualizma, materijalizma, a koje ima za posljedicu 
priklanjanje tradicionalnim metodama rada, odnosno nedovoljan angažman za vlastito educiranje o načinu provođenja sinodskih izjava i odluka: $\gg$ E sad, ja neću bacati krivnju samo na biskupa i nadbiskupiju, i ja sam u nekim stvarima kriv. Dakle, stvar je i moje komocije i neshvaćanja ozbiljnosti. Nije me nitko udario ni po džepu ni po glavi, pa da ja zaronim u to sve dublje. A naš mentalitet nije disciplinirani njemački mentalitet i onda se Crkva mora nositi s time.« (sugovornik 13)

\subsection{SuRAdNJA S VJEROUČitelJima}

Premda je temeljem prethodno iznesenih iskustava župnika vidljivo da veći dio njih ne povezuje postojeće poteškoće $u$ provođenju sinodskih izjava i odluka s vjeroučiteljima, ipak je potrebno naglasiti kako je ukupno 5 (26\%) župnika upozorilo i na poteškoću odnosa vjeroučitelja sa svojom župnom zajednicom: »Jer onda on apsolutno gubi sebe ako se on izdvoji iz župne zajednice. Onda je njegovo vjeroučiteljsko zvanje besmisleno, odnosno on postaje samo profesor religijske pedagogije, nečeg religioznog, a vjeronauk u školi nije tako zamišljen, on je u nužnoj korelaciji s župom. Tako su i programi rađeni. Vjeroučitelj koji nije u župi on više ne zna dijete usmjeriti. On će mu možda dati fantastično znanje, ali bez crkvenosti.« (sugovornik 13) Isti upozoravaju na problem nedovoljne povezanosti dijela vjeroučitelja sa svojom župnom zajednicom zbog čega onda dovode u pitanje i kvalitetu školskoga vjeronauka, koja se po njima očituje u problemu crkvenosti djece i mladih, odnosno u neprenošenju djeci važnosti povezanosti sa župnom zajednicom: »Ja ne predajem vjeronauk u školi. Predavao sam do prije nekih 6, 7 godina. Bilo mi je jako dobro. Ja sam njih onda imao i na misi i na svemu, što god je trebalo. Ja sad s njima imam vrlo slabu komunikaciju... Ja neću reći da vjeronauk u školi nema svoju ulogu i svoju zadaću, ali ja ne znam, možda sam ograničen, ali ja ne mogu shvatiti da nitko ne razumije i ne shvaća što je bitno, a što nebitno, a bitna je znači ta nedjelja, za život zajednice, za život obitelji... Mislim da se naši vjeroučitelji isto trebaju više angažirati. Oni nisu nastavnici ili učitelji kao drugi, oni imaju veće poslanje, šire, gdje ne odgajaju čovjeka samo za neke stvari, nego za puno toga.« (sugovornik 12)

\section{7. ŽUPNA KATEHEZA}

Na koncu su istraživanjem uočene i dvije specifičnije poteškoće. No, s obzirom na to da ih župnici također povezuju s poteškoćama u provedbi Izjava i odluka Druge biskupijske sinode đakovačke i srijemske, iste su uvrštene u prikaz rezultata istraživanja. Prva poteškoća, na koju upozorava 8 (62 \%) od ukupno 13 župnika iz seoskih župa, nadovezuje se na problematiku kateheze mladih i odnosi se na župnu katehezu za sakrament potvrde. Ista je jednim dijelom praktične, odnosno organizacijske naravi te upozorava na nezadovoljstvo župnika odlukom da se župna kateheza u pripravi za primanje sakramenta potvrde odvija s djecom srednjoškolske dobi. Ta- 
kva odluka dovela je do mnogobrojnih poteškoća u njezinoj organizaciji i provedbi te se ona najčešće odvija u kasnim večernjim satima, kada su djeca već iscrpljena od školskih obveza. Poteškoće u njezinoj provedbi javljaju se i subotom zbog činjenice da mnoga djeca tada imaju školsku praksu, zato župnici smatraju da je za seoske župe prikladnija kateheza za sakrament potvrde u osnovnoj školi, kada djeca imaju manje školskih obveza.

Uz navedeno župnici ističu kao poteškoću i trenutačan pristup, odnosno upozoravaju na potrebu uvođenja promjena $u$ osmišljavanju same kateheze, posebice jer je riječ o djeci koja su u dobi kada je jako teško privući njihovu pozornost. Ističu da bi kateheza trebala biti osmišljena ne samo kao dogmatska edukacija, jer taj dio dobivaju na školskom vjeronauku, nego više na način koji potiče i razvija kritičko promišljanje i uvodi u puninu kršćanskoga života: $\gg$ Mislim da pomalo treba razmišljati o napuštanju klasične kateheze. Ne možemo te mlade samo da, već je njima dosta predavanja, umorni su, gladni su, sve ovisi o tome kako ćemo im pristupiti i što ćemo im ponuditi. Dakle, trebalo bi razraditi to na jedan način da ne moramo samo dogmatski pristupati, da moraš nabubati neke stvari. Naravno da to čovjek treba znati, ali za to imaju školski vjeronauk. Neka tome pristupe školski vjeroučitelji i da ja ne moram razmišljati zna li on Deset Božjih zapovijedi. Na meni je da mu pomognem da ga usjetvim u tkivo zajednice, da on to doživi kao nešto svoje, da je to njegova obitelj. To je po meni cilj župne kateheze, one neposredne priprave za krizmu.« (sugovornik 16) Za provedbu takvoga pristupa, koji zapravo Katolička Crkva i promiče još od 2000. godine, kada je Hrvatska biskupska konferencija donijela plan i program za provođenje župne kateheze u obnovi župne zajednice, u okviru kojega stoji potreba za nužnim razlikovanjem školskoga vjeronauka od župne kateheze, kojoj je glavna svrha upravo cjelovitije i dublje uvođenje u iskustvo vjere u konkretnoj vjerničkoj zajednici, župnici ističu kao problem postojeće priručnike koji im ne nude dovoljnu pripomoć: »Dakle trebaš imati župni vjeronauk. Sada mnogi roditelji smatraju da je dovoljno da dijete ide na vjeronauk u školu, tu dobiva neko znanje. Onda se ja pitam što ću ja s njima sada raditi, kada djeca kažu ili ti se ponavljaš ili to smo već radili u školi ... Možda tu djeca treba okupljati ali na drugačiji način. Nekakvi susreti, druženja ali nemamo nikakve vizije za to. Nego kako se koji župnik dosjeti tako se odradi...p pa da oni na taj način svoju vjeru na jedan praktičan način žive. A ono znanje dobivaju u školi. A mi bismo trebali onda samo tu praktičnost pojačati. Onda nemaš ti tu nekog materijala. Nema ujednačenog programa. Opet dolazi sve na ono kako se koji svećenik snađe. Ako nešto i nađeš to je nešto potpuno znanstveno i koje ti ne možeš provesti. Tražili smo da nam nešto daju, ali imaš ono nešto kao u školi.« (sugovornik 15) 


\subsection{SUSRETI I SEMINARI NA NADBISKUPIJSKOJ RAZINI}

Druga poteškoća, na koju upozorava ukupno 12 župnika (63\%), odnosi se na suradnju s nadbiskupijom u pogledu odvijanja formativnih i edukacijskih susreta i seminara za vjernike laike. Tu poteškoću treba se promatrati u odnosu na iznesene rezultate o iskustvima župnika u pronalaženju suradnika vjernika laika gdje se upravo zbog nedostatka istih ona i pojavljuje. Župnici tako upozoravaju kako se na području Đakovačko-osječke nadbiskupije često organiziraju različiti seminari i susreti za koje imaju poteškoća sa slanjem malobrojnih zainteresiranih suradnika: »Evo to je na temelju toga nekakvog umora koji se već nekako pojavio, jer mi imamo stalno, to će sigurno reći drugi kolege, stalno nekakve formacije za suradnike, za susret dekanatski, za regionalni, biskupijski, nadbiskupijski, nacionalnih, mladih, obitelji, ovoga, onoga i onda se to stalno očekuje da mi nekoga animiramo, da netko sudjeluje, jer to su nekako zaključci Sinode, nekako da bi svaka župa trebala imati razne odbore, a mi imamo ljude koji hoće što oni hoće, ... on jednostavno ima i druge obaveze.« (sugovornik 2) Uz navedeno župnici kao poteškoću ističu i način provedbe takvih seminara i edukacije, odnosno neadekvatnu pripremljenost samih predavanja koja se očituje na način da od onih koje uspiju animirati za odlazak na seminare dobivaju povratnu informaciju kako ne žele više odlaziti na iste jer se nisu duhovno obogatili, odnosno smatraju da su predavanja neadekvatno ili previše teorijski osmišljena: »Onda ja ljude pošaljem tamo, nagovoriš ih, a isto ljudi svatko subotom ima svoje privatne mnogobrojne obaveze, onda odvoje svoje vrijeme, onda oni to tamo ne pripreme kako bi trebali. Ti predavači to odrade previše teorijski, onda ljudi nemaju više volje ići tamo. Oni se nisu obogatili, a to je ono neki zamišljaj toga, da se oni tamo educiraju, obogate i da onda mi dođe ovdje i kaže evo vidi župniče to smo tamo, pokušat ćemo mi to ovako ovdje kod nas. Umjesto toga oni više nemaju volju i govore nemojte mene više tamo slati. To je tamo meni gubljenje vremena. Osjeti se kao da i oni to rade samo pro forme. Zato se na terenu postiže možda 20 posto od toga.« (sugovornik 15)

\section{Zaključna razmatranja}

Što u konačnici možemo zaključiti na temelju rezultata ovoga istraživanja? Osim što upozoravaju na postojanje različitih stavova župnika Đakovačko-osječke nadbiskupije prema Izjavama i odlukama Druge biskupijske sinode đakovacke i srijemske, oni pokazuju da, kao posljedicu dosadašnjih iskustava, imamo i jedno opće ozračje nezadovoljstva među župnicima koje upozorava na to kako je provođenje sinodskih izjava i odluka za njih postalo preveliko opterećenje. Upravo zbog silnih neuspjeha kod njih se pojavio određeni otpor i doživljaj istih kao nametnutih, koje se, prema njihovu mišljenju, realno ne može provesti ili može u vrlo malom postotku. Za iste smatraju da ne odgovaraju trenutačnom stanju i mogućnostima rada na gotovo 
svim župama, a posebice manjim seoskim, $\mathrm{s}$ većinskim staračkim stanovništvom za koje je vrlo vjerojatno da nikada ne će imati uvjete za provođenje onoga što se od njih traži. Nezadovoljne jer možda uviđaju što bi trebalo promijeniti, ali ne znaju kako to provesti i treba im stručna pomoć u razvijanju metoda kako prvo pristupiti novoj evangelizaciji tradicionalnih vjernika kod kojih još uvijek nije zaživjela ideja žive župne zajednice, a onda i pronalaženju aktivnih i suodgovornih vjernika laika među istima, odnosno onih koji će dalje širiti evangelizaciju. Nezadovoljne jer uviđaju ono pozitivno u sinodskim izjavama i odlukama, ali ih smeta jedna potpuna neujednačenost $u$ radu župnika, zbog čega i sami počinju posustajati u njihovoj primjeni. I na koncu, možda i najbitnije, nezadovoljne zbog nepostojanja komunikacije i odnosa između župnika i nadbiskupije u kojem bi bilo više razumijevanja za sve poteškoće s kojima se suočavaju, ali i čvršćega stava prema onima koji uopće ne primjenjuju sinodske izjave i odluke.

Stoga se na temelju rezultata ovoga istraživanja može zaključiti kako trenutačno u provođenju Izjava i odluka Druge biskupijske sinode đakovačke i srijemske postoje mnogobrojne poteškoće. $S$ jedne strane rezultati istraživanja pokazuju da se najveći dio poteškoća može povezati s današnjim tradicionalnim vjernikom kod kojega još uvijek nije zaživjela ideja žive župne zajednice i vjernika laika kao aktivnoga i suodgovornoga člana svoje župne zajednice. Time oni upućuju na to kako je nužno promisliti o trenutačnim metodama rada kojima se traži uvođenje vjernika u puninu života bez da ga se najprije obnovi u vjeri jer je činjenica da ovi rezultati pokazuju da se ni nakon deset godina s pomoću sinodskih izjava i odluka nije uspjela provesti nova evangelizacija tradicionalnih vjernika, odnosno $\gg$ njihovo bolje poznavanje onoga $u$ što se vjeruje, istina vjere te potpuno prihvaćanje i dosljedno življenje u skladu s vjerom $\ll, 35$ a koje bi onda imalo za rezultat i veći uspjeh u njihovoj uključenosti kao laika, odnosno aktivnih sudionika u širenju evanđelja i pastoralu župe.

No rezultati isto tako upozoravaju na nedovoljnu osviještenost pojedinih župnika o biti Druge sinode kao sredstva nove evangelizacije ili možda nedovoljnu educiranost, odnosno, riječima prof. Ivančića, da možda još ni sami nisu prošli autoevangelizaciju, koja bi im omogućila da budu sposobni u provođenju daljnje evangelizacije drugih u skladu sa sinodskim izjavama i odlukama. Time rezultati pokazuju da se među većim dijelom župnika može uočiti prisutnost tradicionalno-konzervativnoga tipa evangelizatora ${ }^{36}$ koji još nije spreman suočiti se s izazovima suvremenoga svijeta i čeka da vjernici dođu k njemu ili da živa župna zajednica zaživi sama od sebe bez njegova strpljivoga, ustrajnoga i aktivnoga angažmana. Stoga će se prikaz

\footnotetext{
${ }^{35}$ I. DEVČIĆ, Vjera i nevjera danas, 53-54.

${ }^{36}$ Usp. S. ŠOTA, Poimanje kerigmatske i mistagoške kateheze: osobne i pedagoške značajke te tipologija evangelizatora u Evangelii gaudium, u: Crkva u svijetu 51(2016.)1, 120-142.
} 
rezultata ovoga istraživanja zaključiti s nekoliko preporuka za moguće poboljšanje rezultata u provođenju sinodskih izjava i odluka, a koje se temelje na promišljanjima župnika:

- poboljšanje međusobne komunikacije nadbiskupije i župnika

- poticanje ujednačenosti u radu župnika

- edukacija župnika (i samoinicijativno i na nadbiskupijski poticaj)

- uvođenje etapnoga, naspram integralnoga pristupa

- razlikovanje mogućnosti provođenja Knjige sinode na seoskim (posebice manjim) i gradskim župama (struktura stanovništva)

- profesionalizacija župnih suradnika

- pronalaženje prikladnijih metoda rada s tradicionalnim vjernicima otuđenim od vlastite vjere, nakon čega bi se onda moglo očekivati i veće uspjehe u zaživljenosti ideje laika kao aktivnoga i suodgovornoga člana svoje župne zajednice

- potreba osvješćivanja vjernika o njihovoj suodgovornosti za župnu zajednicu. 


\title{
EXPERIENCES OF PARISH PRIESTS IN (NON)REALIZATION OF STATEMENTS AND DECISIONS OF THE SECOND SYNOD OF THE DIOCESE OF ĐAKOVO AND SRIJEM
}

\author{
Ivana BENDRA*
}

Summary: In the light of the changes in the Church's operations announced by the Second Vatican Council and the process of new evangelization as a form of post-Council attempt to respond to the contemporary challenges and the crisis of faith, the Diocese of Đakovo and Srijem issued, in 2008, the Statements and Decisions of the Second Synod of the Diocese of Đakovo and Srijem, titled You are Christ - for us and for all people. Their task is to be a means and a signpost for the realization of the idea of living Christian communities in which the lay faithful, together with the parish priests, would actively and co-responsibly contribute to the development and pastoral activities of their parishes. Therefore, the aim of this work, on the occasion of the tenth anniversary of their publication, is to present the results of a research that speak about parish priests' experiences in the implementation of the synodal statements and decisions. This will be presented based on the analysis of 19 profound interviews conducted with parish priests of the Đakovo-Osijek Archdiocese in the period from March to May 2018. The analysis of the collected materials, carried out by a qualitative theory-based methodology, resulted in the development of a total of 8 categories which, on the one hand, show past experiences of parish priests in the implementation of the synodal statements and decisions and, on the other hand, several causes which, in their opinion, currently lead to difficulties in implementing the same. In addition, the analysis also points to several recommendations that, in the opinion of the parish priests, could lead to improvements in their further implementation.

Keywords: Statements and Decisions of the Second Synod of the Diocese of Đakovo and Srijem, new evangelization, parish priests, traditional believers, lay faithful, qualitative research.

\footnotetext{
* Ivana Bendra, Ph. D., Institute of Social Sciences Ivo Pilar - Local center Vukovar, J. J. Strossmayera St 25, 32000 Vukovar, Croatia, Ivana.Bendra@pilar.hr
} 